УАK 347.965

ББК 67.75

DOI 10.22394/1682-2358-2020-2-70-75

K.A. Belov, post-graduate student of the Theory of Law Department, Dubna State University, lawyer at the law company "Intel Law"

\section{INSTITUTE \\ OF ADVOCACY \\ IN RUSSIA \\ IN THE SECOND HALF \\ OF THE XIX - \\ EARLY XX CENTURIES}

The institution of Bar in Russia at the stage of its formation - in the second half of the XIX - early XX centuries is studied. In particular, a comprehensive analysis of the place occupied by a lawyer in the legal system of those years, the features of his legal status is conducted. In addition, some problems and difficulties of realization by the lawyer of the professional activity in realities of the designated time are highlighted.

Key words and word-combinations: judicial reform, juries, attorneys, institution, advocacy, human rights activities.
К.А. Белов, аспирант кафедрь теории права Государственного университета "Аубна», юрист юридической компании «Интел праљо» (email: kirillbelov1878@mail.ru)

\section{ИНСТИТУТ \\ ААВОКАТУРЫ В РОССИИ ВТОРОЙ ПОАОВИНЫ ХІХ - НАЧААA XX BEKA}

\begin{abstract}
Аннотация. Исследуется институт адвокатуры на этапе его формирования - во второй половине XIX - начале XX в. Проводится всесторонний анализ статуса адвоката в правовой системе тех лет. Освещаются некоторые проблемы осуществления адвокатом своей профессиональной деятельности в реалиях обозначенного периода.

Ключевые слова и словосочетания: судебная реформа, присяжные поверенные, институт, адвокатура, правозащитная деятельность.
\end{abstract}

\section{И} время имеет больное значение в правовой системе Российской Федерации. Сегодня сложно представить процессуальное право без участия в нем аАвоката. Актуальность рассматриваемой темы закмючается в том, что Аля полноценного понимания места аАвоката в правовом поле современной России необходимо рассматривать аАвокатскую Аеятельность через призму исторического исследования. Кроме того, современные особенности, а такжке проблемные моменты института аАвокатуры зародикись непосредственно в ранние годы его функциони- 
рования, а значит, Аля решения существующих ныне проблем в адвокатской деятельности необходимо представлять их истоки.

В качестве самостоятельной сферы права институт адвокатуры в Российской империи сформировался мишь в XIX в. и с 1864 г. был разделен на два направления: частные поверенные и присяжные поверенные. Существовало несколько условий Амя прохождения отбора по данным направлениям: возраст от двадџати пяти мет, кандидат должен быть русским подАанным, иметь высшее образование в сфере юриспруденщии и предыдущий опыт практики в области права [1].

Адвокат в российском праве выполняет функцию правозаступничества. Аанный термин стал общеупотребительным в 1870-е годы. Правозаступничество можно рассматривать как основной принцип деятельности адвокатов того времени - «заступаться за права другого человека». Правозаступниками считались юристы-правоведы, оказывающие юридическую помощь нужАающимся в ней. Соответственно, институт адвокатуры изначально неразрывно связан с представительством в суде.

Рассматривая институт аАвокатуры в его генезисе, важно отметить, что своим существованием он обязан Судебным уставам, принятым в 1684 г. Кроме того, немаловажным фактом Амя понимания самой сущности адвокатуры является наличие в Аанном институте тех же исторических корней, что и у Аругих институтов правосудия.

Список квалификационных требований, предъявмяемых к адвокату, включал положительную соџиальную репутаџию, достаточный запас капитала, сведения о полной дееспособности и обладание прочими гражАанскими правами. Помимо перечисленного, претендующий на домжность домжен быц состоять на службе в суде по определенной специальности. Аия практики в первую очередь использовалось приготовление сотрудников для службы в ведомствах суда с целью получения правовых знаний мибо выполнение судебной практики в присутствии присяжных. Вся практика Аолжна была быть непосредственно связана с должностью, на которую поступает кандидат. Максимальный срок адвокатской практики составцял пять цет.

Система функционирования адвокатуры отличалась специфической структурой. Корпоративное устройство данного института не бымо характерным Аля рассматриваемого периода и представцяло собой элемент системы правового демократического государства. В рамках отечественной адвокатуры быц провозглашен отказ от бюрократической системы и, распространенной в Аругих правовых, государственных и социальных институтах. Аанное обстоятельство стало первопричиной серьезных изменений в пореформенное время.

С началом функщионирования института адвокатуры необходимо было привлечь к данной деятельности компетентных миџ, сформировав основной кадровый состав присяжных поверенных. Аанный проџесс был проведен достаточно интенсивными темпами в столиџах и Аругих крупных городах. ОАнако в российских регионах формирование адвокатуры, к сожалению, не получимо активного развития. 
Аеятельность института присяжных поверенных в Российской империи четко регламентировалась законодательством, его функционирование характеризовалось высоким профессионализмом, что позволяло поверенным осуществАять и преАставительство в судах.

С основания института адвокатуры и до Октябрьской революџии 1917 г. специальность присяжного поверенного, исполнявшего фундаментальные нормы законодательства, являлась достаточно престижной и важной в обществе. ААвокатские кадры набирались главным образом из высших сословий и наиболее образованных кандидатов. За деятельностью адвокатов, как правило, мюдей интемлектуальных, разносторонних, с навыками ораторского искусства, долей артистизма, а нередко и с китературным даром, с интересом наблюАала обшественность того времени [2] .

Аолжность адвоката приобрела настолько престижный статус, что представители высших сословий нередко отказывались от высоких служебных Аолжностей и прикагаАи множество усилий, чтобы постичь тонкости юридической науки и войти в состав адвокатской комегии. Амя достижения успеха в карьере адвоката следовало принадлежать к адвокатскому сословию или служить при судебном ведомстве. Именно в это время в суде особое развитие получило ораторское искусство. Адвокаты выдемялись в обществе элитарностью, уверенностью в себе, особыми манерами [3] .

Ярко выраженные соџиальные преимушества адвокатского корпуса далеко не всегда воспринималось положительно. Непривияегированные слои общества обычно воспринимали адвокатов как пособников преступников. Такое мнение в значительной степени было обусловлено сравнительно неАавним возникновением института защиты в российском суде в отличие от западной юридической культуры. Манеры поведения адвокаты заимствовали у своих зарубежных комег, где их профессия среди народных масс воспринималась с большим одобрением.

По мнению многих исследователей истории адвокатуры второй половины XIX в., зарождение института правозащитников не послужило поводом к одобрению в народе, а напротив, вызвало негативную реакцию. В среде специалистов и профессионалов адвокатской деятельности также не существовамо корпоративной подАержки. По мере развития отрасли появились новые структуры: Совет присяжных поверенных и Общее собрание присяжных поверенных. Именно эти органы адвокатуры стали определять круг деятельности, прав и обязанностей, уровни несения ответственности по отдеАьным расследованиям для всех служащих.

Поворотным моментом в истории адвокатуры стало формирование системы корпоративной солидарности. ИАеи ее устройства по франџузской модели оказали существенное влияние на взгляды российских правоведов, Так, начали проводиться общие собрания присяжных поверенных по разбору особенностей права и проведения заседаний суда, вводимось разденение на группы во главе с участниками Совета, которые контролировали соблюдение бюрократических обязанностей по ведению письменных документов таких собраний. Совет становияся открытым инструментом дмя изменений в пока несформи-

72 Bulletin of the Volga Region Institute of Administration • 2020. Vol. 20. № 2 
рованной системе. Он занимался вопросами критериев для отбора в адвокаты, обозначением прав и обязанностей самих служащих. По иниџиативе Совета появились общедоступные пространства, в том числе библиотеки и бюро консультаций. ОАним из направлений деятельности Совета было взаимодействие с органами вмасти по вопросам улучшения работы на основе конкретных методик развития и взаимопомоши. Кроме того, Совет заложил определенные правила и нормы аАвокатской деятельности, ставшие впоследствии фундаментальными Аля Аанной профессии [4] .

Появление судебных округов обязано своим появлением периоду реформирования судебной системы. Аанные округа выполняли функщию территориального образования, в котором главным судебным органом явцялась СуАебная палата, которая преАставмяла собой некий контролирующий центр адвокатской деятельности, выполнявший надзорную функџию. В муниџипальных образованиях, где располагался такой орган, адвокатов, естественно, было больше, чем на периферии.

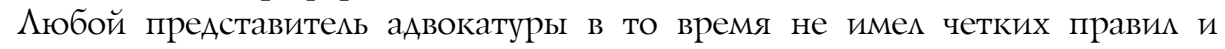
методологий Аля исполнения своих обязанностей; интересы же самого служашего никто не защищал и не обозначал, поэтому окружной суд мог обвинить присяжного поверенного и привлечь к ответственности на основании непроверенной жалобы или по собственному усмотрению. Следует отметить и то, что соблюдение Аисциплины самим судом оставалось недостаточным и голословным. Контроль наА сферой правоприменения со стороны Совета был выше, хотя не имеется достаточных данных и системного анализа дяя обоснованных выводов при разностороннем сравнении деятельности двух этих организаций в ту эпоху. ОАнако можно с уверенностью заявить, что после реформы судебной системы 1864 г. эффективность работы адвокатуры возросла.

ГАавными трудностями, с которыми в те годы сталкивались преАставитеми адвокатуры, являлись преАставительство в суде и правозащита несвободно выбираемых или наемных подсудимых, что требовало контактов с разными мюдьми адвокатов, не имевших специализации в узких областях знаний.

А.А. Гребенщиков указывает, что по сравнению с французскими коммегами, которые занимались сугубо адвокатской деятельностью, поскольку Аругие дела были бы не приняты с точки зрения права и сословия, в ведении отечественных адвокатов имелся широкий перечень различных дел. Это могла быть раздача повесток, проведение процесса выселения, продажа имущества с аукциона и прочее [5]. Профессия адвоката в то время состояла не столько в ораторском искусстве, применяемом в суде, сколько в составлении документации. Беседы с клиентами приходилось проводить в обшественных местах, поскольку выдеменного помещения часто не предоставлямось. Разумеется, в подобных условиях адвокаты не имели возможности не только дмя изучения новых материалов в научных областях юриспруденции, но даже для отслеживания обновлений в существующей системе права. Если адвоката назначали на конкретное Аело, он не имел права отказаться от него без серьезных причин. С подсудимыми по уголовным обвинениям адвокаты могли сами договариваться о защите и представительстве в суде. 
25 мая 1874 г. были опубликованы Правила частных поверенных, в которых обозначалось, что, кроме законных представителей подсудимого и присяжных поверенных в ходе судебного разбирательства со стороны защиты в общих и мировых судах, могут выступать граждане, имеющие свидетельство на право ходатайства. Указанный документ можно было получить на съездах мировых судей, в окружных судах или в Судебной палате.

При этом обнаружилась нехватка присяжных поверенных. Чтобы ее киквидировать, было решено уравнять в правах и обязанностях частных поверенных и помощников присяжных поверенных. Таким образом, стажеры, которые только набирались практики Амя того, чтобы в будушем стать аАвокатом, сразу получили возможность самостоятельной работы. Это сделало теоретическую подготовку к адвокатуре крайне быстрой. За рубежом после получения образования в сфере юриспруденџии требовался стаж работы, тогАа как в России посме получения специальности адвокаты числились помощниками других присяжных поверенных и сразу могли заниматься практикой в карьере, а спустя пять мет перейти в присяжные адвокаты.

В ходе судебной реформы 1864 г. возник институт «псевдоадвокатуры». Физические киџа, выдающие себя за адвокатов, но не имеющие киџензий, специализировались на уголовных делах, где право защиты могло быть передано любому дееспособному и правоспособному гражданину [6]. Аругие представители того же направления пользовались в суде правами поверенных, однако не имели ни миџензии, ни свидетельства Амя наречения себя адвокатами. Это вводимо в заблуждение несведущих граждан, поскольку они не знали тонкостей размичий подобных профессий и оказывацись обманутыми [7] .

ОАна из главных причин аля реформы судопроизводственной системы в конце XIX в. - желание увеличить влияние центрального управления в обмасти оказываемых адвокатурой услуг, а также большое количество по стране получивших образование адвокатов, не согласных с существующей системой. Сушествовал и огромный разрыв межАу соотношением адвокатов на душу населения в регионах и в центральной России. Так, в Московском округе на присяжного поверенного Московской судебной палаты приходилось 10,4 тыс. жителей, в столице - порядка 1,6 тыс. житемей, а в Аругих российских гороАах - около 55 тыс. житемей [3] .

Февральская буржуазно-демократическая революция 1917 г. была обнадеживающим событием к демократическому и соџиалистическому будущему, в том числе в сфере права и закона. В Аекларации Временного правительства в марте 1917 г. заявцямось о признании свободы вероисповедания цичности, свободе слова от цензурирования, свободе народных собраний, отмене сословной сегрегаџии, амнистии дмя политических заключенных; провозглашалось также равноправие, устанавливалась возможность женщин заниматься аАвокатской деятельностью.

ОАнако после Великой Октябрьской соџиалистической революџии меры Временного правительства упразднялись, а институт адвокатуры был обозначен как излишний и буржуазный, что привело к его фактической миквидации.

74 Bulletin of the Volga Region Institute of Administration • 2020. Vol. 20. № 2 
На основании изложенного можно заключить, что институт адвокатуры в России явмялся спорным и почти не принимаемым обществом элементом. ОАнако создание Аолжности присяжных поверенных стало важным шагом на пути к осуществлению защиты демократии в сфере правовой защиты гражАан. При всех реформах судебной системы и проблемах, с которыми в разные времена сталкивался институт адвокатуры, данная профессия явцялась одной из важнейших в правовом гражданском обществе и позволяла защищать права и свободы граждан.

В пореформенный период именно деятельность присяжных поверенных выступила в роли гаранта функционирования основных положений, отраженных в Судебном уставе 1864 г. Более того, институт адвокатуры реализовал себя не только в качестве субъекта правозащитной деятельности, но и в роли органа правосудия и субъекта толкования права.

В итоге можно сделать вывоА о том, что если состояние правовых институтов в настоящее время реализует себя в эффективном функционировании правовых норм, а юриспруденџия имеет вектор непрерывного развития, это в определенной степени результат деятельности адвокатуры в период пореформенной Российской империи. Вместе с тем, несмотря на положительное влияние института адвокатуры на правовые процессы того времени, следует признать тот факт, что реформы в сфере адвокатской деятельности послужили первопричиной ряда проблем, в том числе имеющих отражение в современном праве. Это, к примеру, обязанность ведения присяжными поверенными правых и неправых дел; отсутствие четкого представления об обязанностях адвоката и его роли в уголовном проџессе.

В настоящее время институт адвокатуры, бесспорно, составмяет неотъеммемый атрибут демократии и явмяется показателем уровня развития госуАарства, его соџиальной сферы, а также степени соблюдения прав граждан, открытости общества. В результате проведенного исследования можно сделать вывод, что институт адвокатуры рассматриваемого периода оказал колоссальное влияние на правовую систему пореформенного времени, а равным образом на состояние современной юриспруденции.

\section{Библиографический список}

1. Российское законодательство Х-ХХ вв. Т. 8: Судебная реформа. М., 1991.

2. Савостьянова О.Н. Характеристика профессионально значимых качеств выдающихся представителей адвокатуры середины XIX - начала XX в. (историко-правовое исследование) // Адвокатская практика. 2014. № 3.

3. Гессен И.В. История русской адвокатуры / Издание присяжных поверенных. М., 19141916. Т. 1: Адвокатура, общество и государство, 1864-1914 / под ред. И.В. Гессена. Сер.: История права. М., 1997.

4. Осадчук Е.И. История зарождения и развития адвокатуры в царской России // Адвокатская практика. 2013. № 4.

5. Гребенщиков А.А. Задачи адвокатуры // Журнал гражданского и уголовного судопроизводства. 1886. № 5.

6. Судебная газета. 1888. № 31, 39.

7. Судебная газета. 1892. № 37. 